\title{
Uskonnon oppikirjojen moniäänistymiskehitys ja muuttuva ryhmäkonstruointi
}

Käsittelen tässä kirjoituksessa uskonnon oppikirjateksteissä ilmenevää vuorovaikutusta sitoutumisen näkökulmasta. Tarkastelen toisaalta oppikirjakertojan sitoutumista uskonnolliseen sisältöön, toisaalta kertojan itselleen ja lukijalle olettamia yhteisiä ryhmiä. Aiheen taustalla on yhteiskunnallinen muutos, jonka myötä peruskoulun uskonnonopetus on muuttunut Suomessa koko peruskoulun nelikymmenvuotisen historian ajan vaiheittain tunnustuksettomampaan suuntaan. Kehitys on luettavissa erilaisissa teksteissä: Opetuksen tunnustuksellisuus poistui ensin laista, sitten opetussuunnitelman perusteista. Tekstilajiketjun seuraavana lenkkinä ovatkin muun muassa oppikirjat.

Tässä kirjoituksessa tarkastelen, miten yhteiskunnallinen muutos näkyy oppikirjatekstin kielellisissä valinnoissa. Tekstin kielenpiirteiden tutkiminen tavoitteellisina valintoina perustuu systeemisfunktionaaliseen kielioppiin (esim. Halliday \& Matthiessen 2004) ja siihen pohjaavaan tekstilingvistiikkaan sekä sen piiriin kuuluvaan suhtautumisen teoriaan (Martin \& White 2005). Sitoutumisen diskurssisysteemi, jota voidaan pitää suhtautumisen alasysteeminä (Martin \& White 2005: 92-135), keskittyy niihin kertojan valintoihin, joilla hän ilmaisee lukijalle suhdettaan sanomaansa. Fokus on tekstin moniäänisyydessä: siinä, kenen äänellä näkemyksiä esitetään ja kuinka voimakkaasti näihin näkemyksiin sitoudutaan. Tekstin ääniä tutkittaessa kysymykseksi nousee, millaisia toisia ääniä kertoja tekstiin rakentaa. Uskonnon oppikirjoissa ne ovat tyypillisesti erilaisia kult- tuurisia, uskonnollisia ja muulla tavoin rakentuvia ihmisryhmiä. Sitoutumisen suhteen kiinnostavaa on myös osallisuus näissä ryhmissä - se, mitä ryhmiä kertoja rakentaa itsensä ja lukijan sisäryhmiksi ja mitä hän puolestaan tarkastelee ulkopuolelta. Kyse on siis tekstiin kirjoittuvien osallistujaroolien, kertojan ja lukijan, välisestä vuorovaikutuksesta ja siitä, miten kertoja säätelee tekstin dialogista tilaa ja lukijan responsiivista liikkumavaraa (mts. 103-104; Virtanen 2015: 30-33). Tätä tarkastelen lingvistisen diskurssintutkimuksen menetelmin. Kirjoitus perustuu pro gradu -tutkielmaani (Satokangas 2017).

Sitoutuminen ja ryhmien konstruointi ovat funktionaalisesti määrittyviä tekstinsisäisen vuorovaikutuksen toimintoja, ja ne toteutuvat tekstissä monenlaisin kieliopillis-leksikaalisin keinoin, joista toiset ovat huomattavasti tyypillisempiä kuin toiset. Keskeisimpiä moni- ja yksiäänistä sitoutumista ilmaisevia kielenpiirteitä ovat referoinnin keinot: johtoilmaukset, kuten kommunikaatio- ja mentaaliverbit, sekä mukaan-postpositiolauseke. Ryhmäkonstruoinnin tavallisia ilmaisutapoja ovat puolestaan persoonailmaukset, ryhmien nimeäminen sekä modaaliset ja deiktiset ilmaukset. Uskomisen kaltaisen mentaalisen toiminnan sisällön kielellistä kuvausta voi lähestyä myös projektion käsitteellä. Tämä systeemis-funktionaalisessa kielentutkimuksessa käytetty käsite on referointia lähellä, mutta se määrittyy eri lähtökohdista ja siinä korostuu ajatus toisen asteen representaatiosta ja esitetyn konstruoimisesta ihmisen tietoisuuden tulokseksi. (Shore 2005: 51-54; Lauranto 2017: 
159.) Tässä kirjoituksessa fokuksessa ovat kuitenkin toisen äänen nimeämisen ja siihen viittaamisen keinot tekstin pinnassa näkyvinä kielenpiirteinä, joilla kertoja erottaa toiset äänet omastaan. Toisiin ääniin viittaamisesta käytän referoida-verbiä sen vakiintuneisuuden vuoksi.

Oppikirjoja on Suomessa tutkinut systeemis-funktionaalisesta näkökulmasta Karvonen (1995), englanninkielistä oppikirjadiskurssia samalta pohjalta puolestaan esimerkiksi Coffin (2000). Oppikirjoja käsitellään paljon pro gradu -tutkielmissa, mutta järjestelmällisempi kielitieteellinen oppikirjatutkimus puuttuu (Hiidenmaa 2015: 27). Uskonnon oppikirjoja ja uskonnonopetusta on kuitenkin tutkittu teologian ja etenkin kasvatustieteen alalla. Esimerkiksi Laine (2010) tarkastelee ekumeniaa peruskoulun uskonnon oppikirjoissa; Pyysiäisen (2000) tutkimuskohteena ovat uskontojen opetussuunnitelmatekstit. Lingvistiselle oppikirjatutkimukselle on tilausta, sillä se on ilmeinen keino päästä käsiksi opetuksen käytännön todellisuuteen, oppikirjojen kun tiedetään edelleen ohjaavan kouluopetusta (Ruuska 2014: 77). Uskonnonopetuksen tunnustuksellisuudessa 2000-luvulle tultaessa ilmennyt muutos (ks. esim. Ubani 2013: 70) on käytännössä tapahtunut nimenomaan teksteissä ja niiden kielellisissä valinnoissa, joten tämän laajan kehityksen vaikutusten kartoittamisessa keskeinen ulottuvuus on pedagogisten tekstien tutkiminen. Uskonto on vieläpä perusolemukseltaan hyvin kielellinen aine: hengelliset kirjoitukset ja rituaalit toteutuvat ennen kaikkea kielessä ja kielenä. Tutkimukseni lähtöoletuksena oli, että tunnustuksellisuutta ilmaisisi tekstissä kielenpiirteenä sitoutuminen ja tunnustuksellisuuden muutos näkyisi kielen tasolla esimerkiksi juuri sitoutumisen muutoksena.

Aloitan esittelemällä aineiston, minkä jälkeen tarkastelen oppikirjatekstien moni- ja yksiäänistä sitoutumista eri uskontojen opillisiin näkemyksiin ja sisäl- töön. Sen jälkeen käsittelen sitä, millaisia ryhmiä kertoja rakentaa tekstiin vuorovaikutuksen perustaksi ja millaisia oletuksia niihin kirjoittuu.

\section{Aineisto}

Aineistoni koostuu kuudesta evankelisluterilaisen uskonnon oppikirjasta, jotka on suunnattu peruskoulun seitsemännelle luokalle. Valitsemani kirjat ovat kolmelta eri vuosikymmeneltä: 1970-luvulta (Aikamme uskontokirja 7 ja Peruskoulun uskontokirja 7, tästedes $\mathrm{AU}$ ja PU), 1990-luvulta (Uskon tiet 7 ja Viesti 7, UT ja V) ja 2010-luvulta (Kaiku I ja Mosaiikki, $\mathrm{K}$ ja M). Aineistoon viitatessani olen merkinnyt ensin kirjan lyhenteen ja sivunumeron, sitten ilmestymisvuoden (esim. AU103, 1974).

Analyysi rajautuu ensinnäkin leipätekstiin, sillä se on oppikirjan ydintä ja siksi keskeisintä siihen kirjoittuneen vuorovaikutuksen kannalta. Toiseksi olen rajannut analyysin yhtäältä kristinuskoa ja Raamattua, toisaalta hindulaisuutta käsitteleviin lukuihin. Näin muodostin vertailuasetelman, jonka avulla tutkin eri uskontoihin sitoutumista: evankelisluterilaisten oppikirjojen lähtökohtana olevaan kristinuskoon ja muista maailmanuskonnoista satunnaisesti valitsemaani hindulaisuuteen. Tarkastellakseni sitä, millaiseksi kertoja vuorovaikutuksen rakentaa ja millaisiin yhteisiin ryhmiin hän sen perustaa, valitsin aineistooni lisäksi johdantoluvut sekä ihmisen uskonnollisia taipumuksia yleisesti käsittelevät luvut.

\section{Sitoutuminen ja moniäänisyys}

Tarkastelen kertojan sitoutumista uskonnolliseen sisältöön kiinnittämällä huomion siihen, kenen äänellä uskontojen opillisia näkemyksiä esitetään. Martinin ja Whiten (2005: 99-100) mukaan sitoutuminen voi olla joko yksiäänistä (mono- 
glossic), jolloin kertoja ei tuo näkyviin mahdollisia dialogisia vaihtoehtoja sanotulle, tai moniäänistä (heteroglossic), jolloin kertoja tunnustaa vaihtoehtojen olemassaolon. Yksiäänisen sitoutumisen keskeisin resurssi on sellainen modaalistamaton väitelause, jossa kertoja ei ilmaise toisen äänen läsnäoloa. Tällöin ainoa tekstistä paljastuva ääni on kertojan, eikä kertoja siten tunnusta dialogisten vaihtoehtojen olemassaoloa. Moniäänistäviä resursseja sen sijaan on vuorovaikutusfunktioltaan monenlaisia sen mukaan, millaista asennoitumista ne esitettyyn näkemykseen ilmaisevat. Aineistossani niistä keskeisin on neutraali lähdemaininta (acknowledge, mts. 111, käännös Juvosen 2007).

Kertojan kielellisessä sitoutumisessa uskontokuntiin on aineiston eri-ikäisissä oppikirjoissa selviä ja varsin odotuksenmukaisia eroja. Kehitys on kulkenut 1970-luvun kirjojen sekä yksi- että moniäänisestä sitoutumisesta 2010-luvun aineiston yksinomaiseen ja johdonmukaiseen moniääniseen sitoutumiseen. Tämä muutos koskee evankelisluterilaisten oppikirjojen lähtökohtana olevan kristinuskon näkemysten esittämistä. Vertailukohdaksi valitsemaani hindulaisuuteen ja hinduihin kertoja viittaa läpi aineiston moniäänisesti (ks. esim. 1-3).

(1) Hindut uskovat ihmisen syntyvän maailmaan uudestaan ja uudestaan kunnes lopullinen päämäärä on saavutettu. (AU103, 1974)

(2) Hindujen uskon mukaan jokaisen ihmisen elämää säätelee karman laki. (UT25, 1998)

(3) Hindulaisuuden mukaan jumala voi ilmestyä maan päälle ruumiillisessa muodossa. $\left(\mathrm{K}_{72}, 2015\right)$

Esimerkissä 1 kertoja referoi toisena äänenä ihmisryhmää hindut. Moniäänis- tävänä resurssina (ks. Virtanen 2015: 31) toimii tätä ääntä referoiva johtoilmaus, mentaaliverbi uskoa. Esimerkeissä 2 ja 3 kertoja puolestaan rakentaa toisiksi ääniksi hindujen uskon ja hindulaisuuden ja käyttää tässä johtoilmauksena, ja siten moniäänisen sitoutumisen resurssina, mukaanpostpositiolauseketta. Moniäänistävinä resursseina uskoa-verbi ja mukaan-lauseke ovat kaikille aineiston oppikirjoille ominaisia, ja niitä esiintyy aineistossa ylivoimaisesti eniten. Suhtautumisen teorian luokittelussa ne ovat neutraalin lähdemaininnan keinoja: kertoja merkitsee esitetyn näkemyksen jonkun muun näkemykseksi ilmaisematta asennoitumistaan sitä kohtaan. Uskoa-verbin luokittelu tosin riippuu kontekstista, mutta uskonnon kontekstissa ja tämän tutkimuksen aineistossa se on perusteltua tulkita nimenomaan neutraaliksi lähdemaininnaksi. Kertoja tekee neutraalilla lähdemaininnalla näkyväksi myös muiden näkemysten mahdollisuuden ja tunnustaa dialogisten vaihtoehtojen olemassaolon. Näin kertoja avartaa dialogista tilaa ja jättää lukijalle paljon liikkumavaraa.

Siinä missä aineiston kertojat ovat varsin samankaltaisia kuvatessaan suhtautumista hindulaisuuteen, he eroavat selvästi toisistaan esitellessään kristinuskon opillista sisältöä. 1970-luvun kirjoissa yksija moniäänistävien resurssien käyttö on kaikkein heterogeenisintä. Esimerkeissä 4 ja 5 kertoja esittää näkemyksiä omalla äänellään.

(4) Luomakunnan nerokkuus on osoitusta Luojan viisaudesta. Mutta Jumala ei ole vain viisas, vaan myös luotujaan rakastava Isä. (AU56, 1974)

(5) Jumala syntyi itse maailmaan. Hän tuli ihmiseksi. Hän teki sovinnon maailman kanssa kuolemalla ihmisten puolesta. (PU9192, 1974) 
Esimerkeissä 4 ja 5 kertoja ei nimeä tai referoi muita ääniä eikä tuo mahdollisia vaihtoehtoisia tulkintoja näkyviin myöskään episteemisen modaalisuuden ilmauksilla. Tällaisissa lauseissa lukijalle ei jää responsiivista tilaa valita suhtautumistaan esitettyyn näkemykseen. Lisäksi esimerkin 4 evaluoivat ja affektiset leksikaaliset valinnat - nerokkuus, viisas ja rakastava Isä - ilmaisevat voimakasta asennoitumista, joka yksiäänisessä kehyksessä tulkitaan kertojan omaksi suhtautumiseksi.

1970-luvun oppikirjoissa kertoja esittää kristinuskon näkemyksiä myös toisella äänellä (esim. 6-7).

(6) Kristillisen uskon mukaan maailma ja kaikki, mitä siinä on, ei ole syntynyt sokean sattuman oikusta. Kristityt uskovat, että maailma on Jumalan luoma. $\left(\mathrm{AU}_{53}, 1974\right)$

(7) Raamatun mukaan ihminen on luotu toteuttamaan Jumalan tahtoa maan päällä. (PU87, 1974)

Moniäänistäviä resursseja ovat kummassakin esimerkissä esiintyvä mukaanpostpositiolauseke sekä esimerkissä 6 johtoilmauksena toimiva mentaaliverbi uskoa. Referoitavana toisena äänenä on esimerkissä 6 ensin abstrakti uskonjärjestelmä kristillinen usko ja jälkimmäisessä virkkeessä ihmisryhmä kristityt. Esimerkissä 7 toisena äänenä esitetään Raamattu. Kristinuskon keskeisiä opillisia näkemyksiä esiteltäessä se onkin 1970-luvun aineistossa tyypillinen toinen ääni. Olennainen seikka tässä on rakenteellinen ero 2010-luvun ja varhaisemman aineiston välillä: 2010-luvun oppikirjoissa kristinusko esitellään yhtenä maailmanuskontona muiden joukossa omassa luvussaan, kun taas 1970- ja 1990-luvun aineistossa näin ei ole, vaan kirjat jakautuvat yhtäältä maailmanuskontoja ja toi- saalta Raamattua esittelevään osaan. Siten varhaisemmassa aineistossa vuorovaikutus tapahtuu kristillisen kulttuuripiirin sisältä käsin, jolloin Raamattu näyttäytyy luontevana referoitavana äänenä.

1990-luvun aineistossa kertoja ei enää esitä kristinuskon opillisia näkemyksiä suoraan yksiäänisesti muttei juuri myöskään moniäänisesti. Sen sijaan vuorovaikutuksen rakentaminen kristinuskoon perustuvan kulttuuripiirin sisään näkyy itsestään selvinä esitettävinä ennakkooletuksina (esim. 8). Esimerkistä 8 käy ilmi monikon 1. persoonan ominaisuus valintana, joka nostaa esiin luonnollistumia (Pälli 2003: 102).

(8) On siis syytä tuntea Raamattu, kulttuurimme perusteos. (UT86, 1998)

Voidaan miettiä, keitä ovat ne me, joiden kulttuuriin kertoja viittaa. Tätä kulttuuria määrittää esimerkissä 8 Raamatun merkitys perusteoksena, joten kertojan ja lukijan yhteiseksi lähtökohdaksi rakentuu kristinuskon määrittämä kulttuurinen tausta, kristillinen kulttuuripiiri. Kertoja vieläpä epäsuorasti velvoittaa lukijaa tuntemaan Raamatun käyttämällä nollapersoonaista nesessiivirakennetta. Kertoja asettaa Raamatun yhteiseksi rakentamansa kulttuurin perusteokseksi appositiorakenteella, jonka osien välillä vallitsee samuussuhde. Nollapersoonaisten nesessiivirakenteiden käyttö on aineistolle varsin tyypillistä, ja sen funktioksi voi ajatella modaalisuuden pehmentämisen avoimella indeksikaalisuudella (Satokangas 2017: 88; vrt. Laitinen 1995: 341-343). Lausumalla näin oman näkemyksensä (pronounce, Martin \& White 2005: 127-129) kertoja supistaa dialogista tilaa: hän kyllä tunnustaa vaihtoehtoisten näkemysten olemassaolon mutta merkitsee ne omaansa mitättömämmiksi. Luonnollistumista on nähtävissä myös esimerkissä 9. 
(9) Raamattu on nykyään lähes jokaisen kodin kirjahyllyssä. (V50, 1996)

Vaikka esimerkissä esiintyy universaalinen kvanttori jokainen, ei sen tulkita väittävän, että Raamattu löytyisi lähes jokaisesta kodista maailmassa. Kertoja olettaa itsensä ja lukijan yhteiseksi tulkintakehykseksi tässä kristillisen kulttuuripiirin, johon Raamatulla on ollut suuri vaikutus. Sen sijaan, että kertoja sitoutuisi 1990-luvun aineistossa yksiäänisesti kristinuskon uskonnollisiin näkemyksiin, suhde kristinuskoon syntyy häivytetysti ryhmäkonstruoinnin kautta, itsestään selvänä kulttuurisena lähtökohtana.

2010-luvun oppikirjoissa kertoja kehystää kristinuskon opillisen sisällön neutraalin lähdemaininnan resurssein:

(10) Kristityt uskovat, että Raamatussa Jumala ilmoittaa ihmisille oman tahtonsa, mutta eri kristityt tulkitsevat Raamatun kertomuksia eri tavoin. (M30, 2015)

(11) Kristinuskon mukaan kaikilla ihmisillä on kyky tehdä sekä hyvää että pahaa. (M29, 2015)

Toisena äänenä esimerkissä 10 on ihmisryhmä kristityt ja moniäänistävänä resurssina uskoa-verbi. Että-lauseessa esitetty näkemys asettuu tähän kertojan johtolauseessa rakentamaan moniääniseen kehykseen. Esimerkissä 11 toisena äänenä on kristinusko ja johtoilmauksena mukaanlauseke. Neutraalin lähdemaininnan keinoina nämä ovat aineistossa tyypillisimpiä (vrt. esimerkkeihin 1-3, 6-7). Merkille pantavaa moniäänistävissä ilmauksissa on kieliopillis-leksikaalisten keinojen eriytyminen referoitavan äänen mukaan. Kertoja referoi uskoa-verbillä ihmisryhmää (kristityt, hindut), mukaan-postpositiolausekkeella puolestaan abstraktia uskontokuntaa tai uskonjärjestelmää (kris- tillinen usko, hindulaisuus). Tämä jako kattaa koko aineiston.

Vaikka uskoa-verbi ja mukaan-lauseke ovat selvästi aineiston yleisimpiä moniäänistäviä resursseja, tähän tehtävään käytetään myös muita kieliopillis-leksikaalisia keinoja. Niitä ovat esimerkiksi mentaaliverbi ajatella johtoilmauksena sekä kommunikaatio- ja mentaaliverbien nominaalijohdokset. Esimerkissä 12 kristinuskon opillinen näkemys asetetaan toisen äänen kehykseen nominaalijohdoksella ajatus, joka saa määritteekseen että-lauseen.

(12) Kristinuskon tärkeimpiä ajatuksia on, että Jeesus kuoli ristillä sovittaen ihmisten synnit ja nousi kuolleista voittaen kuoleman. $(\mathrm{K} 48,2015)$

Monikon partitiivissa oleva ajatus toimii että-lauseessa esitettyä näkemystä luokittavana yleissubstantiivina (vrt. Karvonen 1995: 123). Kertoja sijoittaa luokittelemansa näkemyksen toisen äänen kehykseen asettamalla nimeämänsä äänen, uskonjärjestelmä kristinuskon, nominaalistuksen genetiivimääritteeksi. Mentaaliverbin nominaalistus voi saada genetiivimääritteekseen myös nimetyn ihmisryhmän, kuten mukaan-lausekkeessa Kristittyjen käsityksen mukaan (M29, 2015). Tässä tapauksessa nominaalistus itsessään asettuu toiseksi ääneksi, tietyn ryhmän yhteiseksi ajatuskokonaisuudeksi, jota kertoja referoi mukaan-lausekkeella.

2010-luvun aineistossa kertoja pysyttäytyy visusti moniäänistävien resurssien käytössä uskonnollista sisältöä esittäessään, kun taas 1970-luvun aineistossa esiintyy vielä kertojan yksiäänistä sitoutumista kristinuskon näkemyksiin. 1990-luvun oppikirjojen kertoja puolestaan häivyttää kristinuskon taustalle oletetuksi yhteisen kulttuurin perustaksi. Näissä kirjoissa korostuukin taustaoletusten merkitys lukijan liikkumatilan säätelyn keinoina. Vuorovaikutus ja teks- 
tiin kirjoittuneen lukijan suhde uskonnolliseen sisältöön syntyy paitsi siitä, miten kertoja säätelee dialogista tilaa monija yksiäänisen sitoutumisen resursseilla, myös siitä, millaiselle pohjalle kertoja tuon tilan rakentaa. Esittelen seuraavaksi niitä ryhmiä, joiden jäseneksi kertoja lukijan kirjoittaa.

\section{Ryhmien konstruointi ja lukijalle rakennetut sisäryhmät}

Ryhmiä voidaan konstruoida tekstiin mitä moninaisimmin tavoin, mutta tutkimassani aineistossa tyypillisimpiä leksikaaliskieliopillisia keinoja ovat persoonailmaukset (pronominit, possessiivisuffiksit ja persoonapäätteet) sekä ryhmän nimeäminen (suomalaiset, nuoret, kristityt). Ryhmäkonstruoinnin kannalta erityisesti monikon 1. persoona ja siihen liittyvä pronomini me ovat keskeinen tarkastelun kohde, sillä ne rakentavat sisäryhmän. Sen sijaan monikon 3. persoona ja siihen liittyvä pronomini he ovat tulkinnanvaraisempia ja riippuvaisempia kontekstistaan. Esimerkiksi omasta ryhmästä 3. persoonassa puhuminen voi olla objektivoiva strategia. Uskonnon oppikirjojen kertoja käyttää tällaista jotakin ryhmää ulkoapäin tarkastelevaa näkökulmaa aineistossa paljon, ja olen nimittänyt sitä tutkivaksi katseeksi. Tekstiin rakentuvien ryhmien ja niiden luonteen määrittäminen perustuukin kontekstivihjeisiin ja tekstin tulkitsemiseen vuorovaikutuskokonaisuutena.

1970-luvun aineistossa kertoja rakentaa vuorovaikutuksen yhteisen ihmisyyden perustalle. Ajan uskonnonopetuksessa oli vallalla persoonallisuuspsykologinen suuntaus (Ubani 2013: 63), joka näkyy sekä oppikirjojen sisällössä että niiden interpersoonaisissa piirteissä: kertoja käsittelee ihmiseksi kasvamista ja yleisinhimillisiä kokemuksia ja kysymyksiä sekä käyttää monikon 1. persoonaa viittausalaltaan laajasti, siten että se kattaa kaikki ihmiset. Tällä tavalla kertoja luo vuorovaikutus- suhteen lukijaan yhteisen ihmisyyden kautta. Tämän suuren ryhmän yleistävyyttä korostaa, että samaviitteisenä laajan monikon 1. persoonan kanssa kertoja käyttää passiivia, avoimeksi jätettyä persoonaa sekä monikon 3. persoonaa, jonka subjektina toimii ihmiset-NP tai pronomini he. Persoonaviittausten moninaisuus on nähtävissä esimerkeissä 13 ja 14.

(13) Eräässä suhteessa ihmiset ovat kaikki samanlaisia: he tarvitsevat toisiaan riippumatta siitä, minkä ikäisiä he ovat. Jokainen meistä tarvitsee ystäviä. Me tarvitsemme toistemme elämänkokemusta ja neuvoja. (PU4, 1974)

(14) Mutta osaammeko tarkemmin sanoa, millaisia yksilöinä olemme? Sopivien sanojen löytyminen saattaa tuottaa vaikeuksia. - On mahdotonta kertoa sellaisesta, josta ei mitään tiedä. (AU7, 1974)

Esimerkissä 13 kertoja viittaa aluksi 3. persoonassa geneeriseen kategoriaan ihmiset ja vaihtaa sitten saumattomasti 1. persoonaan. Näin hän aluksi esittelee yleisesti ihmisten tarpeen sosiaaliseen kanssakäymiseen ja tuo asian sitten lähemmäksi lukijaa siirtymällä puhumaan sisäryhmästä me käsin. Tämän kaltaisia toimintokuvioita, joita voisi luonnehtia johdattelutai houkuttelukuvioiksi, esiintyy useita. Esimerkissä 13 on käytetty samaviitteisinä heitä ja meitä. Esimerkissä 14 taas ensimmäisen virkkeen monikon 1. persoona ja seuraavien virkkeiden avoimeksi jäävä kokija viittaavat samaan, ihmisten ylipäänsä muodostamaan laajaan ryhmään. Kertoja ankkuroi monikon 1. persoonalla esittämänsä kysymyksen yhteiseksi ja ilmaisee siten lukijalle, että identiteetin pohtiminen on yleisinhimillistä. Jälkimmäisissä virkkeissä avoimeksi jätetty kokija toteuttaa samaa tehtävää hieman toisin: se tarjoaa lukijalle mahdollisuuden samastua 
esitettyyn mutta jättää tälle myös responsiivista tilaa ja mahdollisuuden olla samastumatta (Pälli 2003: 68; ks. myös Laitinen 1995; Helasvuo \& Laitinen 2006).

1970-luvun aineiston persoonailmausten moninaisuus näyttää, kuinka joustava persoonajärjestelmä käytännön kielenkäytössä on; teksti on ymmärrettävää ja sujuvaa, vaikka kertoja vaihtaa persoonasta toiseen kesken kappaleen ilman selityksiä. Näillä asennonvaihdoilla on kuitenkin johdonmukainen interpersoonainen tehtävä: houkutella lukija vuorovaikutussuhteeseen. Kertoja siis viestii, että elämänkysymykset ovat kaikille yhteisiä ja että niiden kanssa painivat muutkin, ja kutsuu lukijan pohtimaan niitä kanssaan. Tähän hän käyttää moninaisia persoonailmauksia - laajaa me-viittaamista ja eläytyvää nollapersoonaa. Näin erilaiset persoonailmaukset rakentavat yhteistä tilaa tekstin sisälle, ja yhteiseksi sisäryhmäksi rakentuu elämän kysymyksiä pohtivien ihmisten, eli kertojan mukaan kaikkien ihmisten, laaja joukko.

1990-luvun oppikirjoissa kertoja rakentaa vuorovaikutuksen lukijaan varsin toisenlaiselle pohjalle: oletettuna yhteisenä lähtökohtana on suomalaisuus (esim. 1516).

(15) Onko meistä suomalaisista kohtaamaan vieraita kulttuureja, joihin kuuluu myös omasta perinteestämme poikkeava uskonto? (UT8, 1998)

(16) Monet suomalaisetkin matkustavat vuosittain lomalle maailman eri kolkkiin; Euroopasta Aasiaan, Afrikkaan tai vaikkapa Australiaan. Myös täällä kotimaassa pääsemme yhä enemmän tekemisiin vieraiden kulttuurien edustajien kanssa. $\left(V_{7}, 1996\right)$

Esimerkissä 15 kertoja luo sisäryhmän ja samalla määrittää sen eksplisiittisesti yh- distämällä persoonapronominin $m e$ ja ryhmänimityksen suomalaiset appositiorakenteeksi me suomalaiset. Tällä sisäryhmällä on myös oma, muista erottuva perinne, jonka kertoja merkitsee possessiivisuffiksilla -mme. Sisäryhmä on olemassa kertojan diskurssissa suhteessa muihin, kertojan nimeämiin vieraisiin kulttuureihin. Esimerkissä 16 esiintyy niin ikään me-ryhmä, tällä kertaa verbin persoonapäätteen -mme kautta. Ensimmäisessä virkkeessä kertoja esittelee nimeämänsä ryhmän suomalaiset, ja jälkimmäisessä virkkeessä hän ankkuroi itsensä ja lukijan yhteisen näkökulman Suomeen deiktisellä proadverbilla täällä ja sen kanssa samaviitteisellä nimityksellä kotimaa. Deiktinen täällä vertautuu monikon 1. persoonaan siinä, että lukija lukee täällä-sanan merkitykseksi mitä haluaa, niin kuin hän saattaa mieltää kuuluvan meihinkin. Se, mihin kertoja kontekstivihjeiden perusteella ilmauksen asemoi, kertoo, millaista lukijaa hän tekstiin rakentaa. Leksikaalisena valintana affektisia sivumerkityksiä kantava kotimaa rakentaa voimakkaasti sisäryhmää Suomea kotimaanaan pitävistä. Viimeisen virkkeen me-viittaus luetaan siis kontekstin perusteella samaviitteiseksi ryhmänimityksen suomalaiset kanssa, ja tätä ryhmää määrittää lisäksi yhteinen kotimaa. Rakentaessaan yhteistä maaperää lukijan kanssa 1990-luvun aineiston kertoja tekee taustaoletuksia ja nojaa luonnollistuneisiin ilmaisutapoihin ja näkökulmiin.

2010-luvun aineistossa kertojan ja lukijan vuorovaikutusta leimaavat runsas impersonaalisuus, käsitteenmäärittelyt ja se, että kertoja tarjoaa tiedon lukijalle valmiina. Näistä piirteistä syntyvä objektiivinen ote jättää lukijalle paljon responsiivista liikkumatilaa. Kertoja esittää käsitteenmäärittelyä ekvatiivilauseilla ja passiivimuotoisilla niin sanotuilla sanomislauseilla (vrt. Karvonen 1995: 122). Tätä havainnollistavat seuraavat esimerkit: 
(17) Ateismi on aatesuunta, jossa ei uskota jumalien olemassaoloon. (M21, 2015)

(18) Tätä kutsutaan sekularisaatioksi eli maallistumiseksi. $(\mathrm{K} 8,2015)$

Esimerkissä 17 kertoja esittelee käsitteen ateismi määrittelemällä sen ekvatiivilauseella, esimerkissä 18 taas sekularisaation passiivimuotoisella sanomislauseella. Kummassakin käsitteet määrittelyineen tarjotaan lukijalle annettuina, ja esimerkissä 17 käsitettä käyttävä yhteisökin on häivytetty; käsite vain on. Esimerkissä 18 kertoja konstruoi passiivilla toimijakollektiivin, jonka tekemisiin vedota ja jonka äänellä puhua (Pälli 2003: 112; Virtanen 2015: 46). Tässä tapauksessa kyseessä on uskontoa analyyttisesti tarkasteleva kollektiivi, johon liittymistä kertoja lukijalle tarjoaa.

Esimerkit 19 ja 20 eroavat edellisistä siinä, että niissä kertoja myös nimeää esiin nostamansa kollektiivin näkökulman.

(19) Tieteellinen uskonnontutkimus tarkastelee uskontoja monesta eri näkökulmasta. (M13, 2015)

(20) Uskontotiede tutkii uskontoa maailmanlaajuisena ilmiönä ja pyrkii ymmärtämään kunkin uskonnon erityislaatuisuutta. (K1O, 2015)

Esittelemällä uskontotieteellisen näkökulman kertoja ilmaisee pohjaavansa tarkastelutapansa siihen. Samalla hän eksplikoi lukijalle tarjoamakseen vuorovaikutuksen kehykseksi kollektiivin, joka tarkastelee uskontoja tämän tietyn tieteenalan näkökulmasta. Koska niin käsitteet kuin näkökulma esitetään passiivissa (esim. 18) tai 3. persoonassa (esim. 19-20), lukijan liikkumavara pysyy suurena.

Omanlaisiaan, kertojan ja lukijan vuorovaikutuksessa korosteisia jaksoja ovat kirjan tulevaan sisältöön orientoivat metatekstiosiot sekä uskonnon opiskelun merkitystä perustelevat jaksot, joita esiintyy kaikissa aineistoryhmissä. Persoonailmaukset vaihtelevat, ja kertoja orientoi lukijaa kirjan vuorovaikutussuhteeseen luomalla yhteisen me-ryhmän mutta myös yksikön 2. persoonan puhuttelun kautta (esim. 21-22).

(21) Tässä kirjassa sinulle pyritään antamaan kuva siitä, miten eri ihmiset ovat kokeneet Jumalan. Samalla sinulle esitellään myös muita uskontoja kristinuskon ohella. (PU17, 1974)

(22) Tutustumme näihin kaikkiin uskontoihin. Perehdymme myös juutalaisuuteen, jonka kannattajamäärä on melko pieni, mutta merkitys sitäkin suurempi. Lisäksi tarkastelemme vielä Japanin perinteistä uskontoa, shintolaisuutta. (V10, 1996)

Esimerkissä 21 kertoja puhuttelee lukijaa suoraan yksikön 2. persoonassa ja kuvaa kirjan sisältöä - omaa toimintaansa passiivimuotoisilla verbeillä. 1970-luvun oppikirjat, joissa kertoja käyttää ylipäänsä vaihtelevimmin persoonaviittauksia, ovat ainoita, joissa lukijaa puhutellaan yksikön 2. persoonassa. Esimerkissä 22 kertoja ja lukija puolestaan tutustuvat oppikirjan kehyksessä uskontoihin yhteisessä sisäryhmässä. Tässä sisäryhmän muodostavat kertoja ja lukija, mikä poikkeaa aineistolle tyypillisistä laajemmista me-ryhmistä. Huomattavaa on persoonailmauksista rakentuva lukijan erilainen asema: esimerkissä 22 kertoja esittää kirjan sisällön läpikäymisen yhteisenä toimintana, kun taas esimerkissä 21 lukija ottaa vastaan tietoa ja tiedon antaminen tapahtuu ulkoapäin.

Uskonnon opiskelua perustelevissa jaksoissa kertoja käyttää me-viittausta tai 
nollapersoonaa. Persoonan valinta ei rajaudu osa-aineiston mukaan, sillä molempia esiintyy läpi aineiston. Näissä jaksoissa modaaliset ilmaukset, etenkin nesessiivirakenne, ovat yleisiä (esim. 23-24).

(23) Tällainen maailmanlaajuinen ilmiö, uskonto, on syytä tuntea. (K9, 2015)

(24) Opiskelemme uskontoja, jotta ymmärtäisimme paremmin maailmaa jossa elämme ja ihmisiä joita tapaamme. (M11, 2015)

Esimerkissä 23 nesessiivirakenteen ilmaisema deonttinen modaalisuus kohdistuu indeksiltään avoimeen ja yleistävään nollapersoonaan. Uskonnon oppikirjassa on ilmeistä, että velvoittavuus koskee lukijaa, mutta sen laajentaminen yleiseksi samalla pehmentää juuri lukijaan kohdistuvaa velvoittavuutta. Modaalisella ilmauksella kertoja lausuu näkemyksensä muita mahdollisia näkemyksiä voimakkaampana (ks. myös esim. 8), jolloin dialoginen tila supistuu. Kuitenkin myös muiden näkemysten olemassaolo tulee näkyväksi; lukijan voi esimerkiksi ajatella olevan lähtökohtaisesti sitä mieltä, ettei uskontoa tarvitse tuntea, jollei ole siitä erityisemmin kiinnostunut. Esimerkissä 24 kertoja luo monikon 1. persoonalla rajoiltaan epämääräisen laajan sisäryhmän, jonka kehyksessä kertoja ja lukija yhdessä toimivat. Tällaisessa väitelauseessa kertoja ei jätä lukijalle liikkumavaraa, vaan tämä on ikään kuin pakotettu sisäryhmän jäsenenä osallistumaan toimintaan. Monikon 1. persoona kuitenkin rakentaa toiminnasta laajempaa ja yhteisempää, mikä keventää yksittäisen jäsenen osuutta - kuten tekee edellisessä esimerkissä nollapersoona.

\section{Lopuksi}

Peruskoulun 7. luokan uskonnon oppikirjojen vuorovaikutus ja sen kehykseen rakentuva dialoginen tila on muuttunut neljän viime vuosikymmenen aikana: 2010-luvun uskonnonkirjassa dialoginen tila on avarampi ja lukijalla enemmän liikkumavaraa. Kertoja lisäksi asemoi oppikirjan lukijan osaksi yhteistä sisäryhmää, johon vuorovaikutus pohjaa ja jonka puitteissa asioita tarkastellaan. Merkille pantavaa on, kuinka selviä erot eri vuosikymmenten kirjoihin kirjoittuneen vuorovaikutuksen perustoissa ovat ja toisaalta kuinka johdonmukaisen yhtenäistä vuorovaikutuspohjan rakentaminen on kunkin aineistoryhmän kahden teoksen välillä. Tekstinsisäinen vuorovaikutus on kirjoittunut johtoilmauksiin, verbin persoonaan, persoonapronomineihin ja muihin kertojan leksikaalis-kieliopillisiin valintoihin. Nämä valinnat rakentavat dialogisen tilan säätelyn ja ryhmäkonstruoinnin kautta eri-ikäisiin oppikirjoihin varsin erilaisen lukijan, ja muuttuva lukija puolestaan kertoo ympärillään muuttuvasta yhteiskunnasta.

HenRI Satokangas etunimi.sukunimi@helsinki.fi

Kirjoittaja on suomen kielen väitöskirjatutkija Helsingin yliopistossa.

\section{Aineistolähteet}

$\mathrm{AU}=$ Hyrck, Matti - Tuominen, Antti - Virkkunen, Lauri - Virkkunen, T. P. 1974: Aikamme uskontokirja 7. Helsinki: WSOY.

$\mathrm{K}$ = Lackström, Kirsi-Maria - Mikkola, Kati - Mäkelä, Saara - Soikkeli, Vesa 2015: Kaiku I. Uskontojen maailma. Helsinki: Otava.

M = Jussila, Pia - Kartano, Minna - Sakaranaho, Tuula - Virkkula, Anita 2015: Mosaiikki. Uskonnot maailmassa. Helsinki: Edita.

$\mathrm{PU}=$ Arhinmäki, Erkki - Knuuttila, Simo

- Kosonen, Katri - Laakso, Sauli -

Nurminen, Uolevi 1974: Peruskoulun 
uskontokirja 7. Helsinki: Valistus.

$\mathrm{UT}=$ Halme, Lasse - Lindqvist, Martti Paloheimo, Elina - Paloheimo, Matti - Saloranta, Leena 1998: Uskon tiet 7. Helsinki: WSOY.

$\mathrm{V}=$ Isotalo, Seppo - Vartiainen, Katriina 1996: Viesti 7. Yläasteen uskontokirja. Helsinki: Otava.

\section{Kirjallisuuslähteet}

Coffin, Caroline 2000: History as discourse. Construals of time, cause and appraisal. Sydney: University of New South Wales.

Halliday, M. A. K. - Matthiessen, Christian M. I. M. 2004: An introduction to functional grammar. London: Arnold.

Helasvuo, Marja-Liisa - Laitinen, LEA 2006: Person in Finnish. Paradigmatic and syntagmatic relations in interaction. - Marja-Liisa Helasvuo \& Lyle Campbell (toim.), Grammar from the human perspective. Case, space, and person in Finnish s. 173-207. Amsterdam: John Benjamins.

Hitdenmaa, Pirjo 2015: Oppikirjojen tutkimus. - Helena Ruuska, Markku Löytönen \& Anne Rutanen (toim.), Laatua! Oppimateriaalit muuttuvassa tietoympäristössä s. 27-39. Helsinki: Suomen tietokirjailijat ry.

Juvonen, Riıtta 2007: Suhtautumisen systematiikkaa. - Virittäjä 111 s. 431-435.

Karvonen, Pirjo 1995: Oppikirjateksti toimintana. Helsinki: Suomalaisen Kirjallisuuden Seura.

Laine, Ant ti 2010: Ekumenia evankelisluterilaisen, ortodoksisen ja katolisen uskonnon perusopetuksen oppikirjoissa. - Eero Ropo, Harry Silfverberg \& Tiina Soini (toim.), Toisensa kohtaavat ainedidaktiikat. Ainedidaktiikan symposiumi Tampereella 13.2.2009 s. 191-202. Tampereen yliopiston opettajankoulutus- laitoksen julkaisuja A31.

LAitinen, LEA 1995: Nollapersoona. - Virittäjä 99 s. 337-358.

LAURAnTO, YRJö 2017: The projected directive construction and object case marking in Finnish. - Journal of Estonian and Finno-Ugric Linguistics 8 (2) s. 155-19o. https://doi.org/10.12697/jeful.2017.8.2.06.

Martin, J. R. - White, P. R. R. 2005: The language of evaluation. Appraisal in English. Hampshire: Palgrave McMillan.

PyysiäINEN, MARKKU 200o: Yksi oppiaine, seitsemän opetussuunnitelmaa. Peruskoulun ja lukion opetushallituksen 1990-luvulla vahvistamien uskonnon opetussuunnitelmien tunnustuksellinen luonne. Helsingin yliopiston opettajankoulutuslaitoksen tutkimuksia 223.

PäLli, Pекка 2003: Ihmisryhmä diskurssissa ja diskurssina. Tampere: Tampere University Press.

Ruuska, Helena 2014: Ei oppikirja ojaan jouda. - Tommi Inkinen, Markku Löytönen \& Anne Rutanen (toim.), Kirja muuttuvassa tietoympäristössä s. 77-87. Helsinki: Suomen tietokirjailijat ry.

SATOKAngas, Henri 2017: Moniäänistyvä uskonnon oppikirja. Pro gradu -tutkielma. Helsingin yliopiston suomen kielen, suomalais-ugrilaisten ja pohjoismaisten kielten ja kirjallisuuksien laitos.

Shore, Susanna 2005: Referoinnista projektioon ja metarepresentaatioon. - Markku Haakana \& Jyrki Kalliokoski (toim.), Referointi ja moniäänisyys s. 44-82. Helsinki: Suomalaisen Kirjallisuuden Seura.

Ubani, Martin 2013: Peruskoulun uskonnonopetus. Jyväskylä: PS-kustannus.

Virtanen, Mikко 2015: Akateeminen kirja-arvio moniäänisenä toimintana. Helsingin yliopiston suomen kielen, suomalais-ugrilaisten ja pohjoismaisten kielten ja kirjallisuuksien laitos. 